\title{
Pengaruh Kompensasi, Motivasi dan Disiplin Kerja Terhadap Kinerja Karyawan pada PT Livia Mandiri Sejati Banyuwangi
}

\author{
Anissaul Istifadah ${ }^{1}{ }^{*}$, Budi Santoso ${ }^{2}$ \\ 1,2Fakultas Ekonomi Program Studi Manajemen Universitas Muhammadiyah Jember
}

\author{
A R T I C L E I N F O \\ Article history: \\ Received 19 May 2019 \\ Received in revised form \\ 16 June 2019 \\ Accepted 15 July 2019 \\ Available online 26 August \\ 2019 \\ Kata Kunci: \\ kompensasi, motivasi, \\ disiplin kerja, kinerja \\ karyawan \\ Keywords: \\ compensation, motivation, \\ work discipline, employee \\ performance
}

\begin{abstract}
A B S T R A K
Penelitian ini bertujuan unuk menganalisis pengaruh kompensasi, motivasi dan disiplin kerja terhadap kinerja karyawan pada PT Livia Mandiri Sejati Banyuwangi. Data yang digunakan dalam penelitian ini berupa data primer yang diperoleh melalui penyebaran kuesioner kepada karyawan PT Livia Mandiri Sejati Banyuwangi. Adapun yang menjadi populasi dalam penelitian ini adalah karyawan sebanyak 98 orang di PT Livia Mandiri Sejati Banyuwangi. Penentuan sampel menggunakan studi populasi. analisis data menggunakan analisis regresi linear berganda. Berdasarkan hasil pengujian hipotesis dapat dinyatakan bahwa kompensasi berpengaruh terhadap kinerja karyawan pada PT Livia Mandiri Sejati Banyuwangi atau H1 diterima. Motivasi berpengaruh terhadap kinerja karyawan pada PT Livia Mandiri Sejati Banyuwangi atau H2 diterima. Disiplin kerja berpengaruh terhadap kinerja karyawan pada PT Livia Mandiri Sejati Banyuwangi atau $\mathrm{H} 3$ diterima.
\end{abstract}

\section{A B S T R A C T}

This study aimed to analyze the effect of compensation, motivation and work discipline on employee performance at PT Livia Mandiri Sejati Banyuwangi. The data used in this study were primary data that obtained through questionnaires to employees of PT Livia Mandiri Sejati Banyuwangi. The population in this study was 98 employees at PT Livia Mandiri Sejati Banyuwangi. Determination of samples using population studies. data analysis using multiple linear regression analysis. Based on the results of testing the hypothesis it can be stated that compensation affects the performance of employees at PT Livia Mandiri Sejati Banyuwangi or H1 accepted. Motivation affects the performance of employees at PT Livia Mandiri Sejati Banyuwangi or $\mathrm{H} 2$ received. Work discipline affects the performance of employees at PT Livia Mandiri Sejati Banyuwangi or H3.

\footnotetext{
* Corresponding author.

E-mail addresses: AnissaulIstifadah13@gmail.com (Anissaul Istifadah)
} 


\section{Pendahuluan}

Kinerja merupakan suatu proses tentang bagaimana pekerjaan berlangsung untuk mencapai hasil kerja. Kinerja individu yang baik dapat meningkat apabila ada kesesuaian antara pekerjaan dan kemampuan Kinerja individu yang baik dapat meningkat apabila ada kesesuaian antara pekerjaan dan kemampuan. Dari definisi diatas kinerja merupakan output dari serangkaian proses pekerjaan sehari-hari yang dijalani oleh setiapa karyawan dengan ketetapan waktu yang ditentukan, untuk mencapai hasil yang baik, kita harus berupaya untuk meningkatkan kinerja kita melalui budaya kerja yang meliputi perilaku,kedisiplinan,kejujuran, dll (Wibowo. 2014).

Kompensasi merupakan sesuatu yang diterima pegawai sebagai penukar atas kontribusi jasa mereka bagi organisasi. Apabila di kelola dengan baik maka kompensasi membantu organisasi mencapai tujuan dan memperoleh, memelihara, dan menjaga pegawai dengan baik. Sebaliknya tanpa kompensasi yang memadai maka pegawai yang ada pada saat ini sangat mungkin akan meninggalkan organisasi, dan organisasi akan kesulitan untuk merekrut kembali pegawai yang sesuai dengan kebutuhan (Werther dan Davis ,1996).

Motivasi merupakan setiap organisasi ingin mencapai tujuan, untuk mencapai tujuan tersebut, peranan manusia yang didalamnya sangat penting untuk menggerakkan manusia agar sesuai yang dikehendaki orgnisasi, maka haruslah dipahami motivasi manusia yang bekerja didalam organisasi tersebut, karena motivasi inilah yang menentukan perilaku orang-orang untuk bekerja, atau dengan kata lain perilaku merupakan cerminan yang paling sederhana dari motivasi (Sutrisno,2009).

Disiplin Kerja merupakan suatu alat yang digunakan para manajer untuk berkomunikasi dengan karyawan agar mereka bersedia untuk mengubah suatu perilaku serta bebagai upaya untuk meningkatkan kesadaran dan kesediaan seseorang mentaati semua peraturan perusahaan dan normanorma social yang berlaku" (Rivai ,2015).

Penelitian dengan tema sejenis pernah dilakukan sebelumnya oleh, Siagian (2015) menunjukkan bahwa pelatihan, kepuasan kompensasi, motivasi dan disiplin kerja berpengaruh signfikan terhadap Kinerja Karyawan. Muawanah (2016) menunjukkan bahwa Kompensasi, Motivasi dan Disiplin Kerja secara simultan berpengaruh signfikan terhadap kinerja karyawan. Ayer (2016) menunjukkan bahwa Motivasi dan Disiplin Kerja berpengaruh signfikan terhadap Kinerja Karyawan. Fadilah (2017) menunjukkan bahwa Disiplin Kerja berpengaruh signfikan terhadap Kinerja Karyawan. Purnomo (2017), Santoso,dkk (2017) menunjukkan bahwa Motivasi Kerja, Kompensasi dan komunikasi berpengaruh signfikan terhadap kinerja karyawan

PT Livia Mandiri Sejati Banyuwangi merupakan salah satu distributor AMDK dengan merk "AQUA" ruang lingkup bisnisnya bergerak di bidang air minum dalam kemasan. Perusahaan ini memiliki kredibilitas yang tinggi, karena menjadi salah satu produsen distributor terbesar di Banyuwangi. Selain memasarkan produk (sales), PT. Livia Mandiri Sejati ini juga menyediakan jasa isi ulang AMDK berupa galon. Disini perusahaan dituntut untuk lebih professional dan mampu bersaing secara global. Untuk itu, perusahaan ini membutuhkan SDM yang memiliki kinerja yang optimal agar dapat bersaing secara kualitas pelayanan agar menciptakan kemajuan perusahaan. pada kenyataannya kinerja karyawan pada perusahaan tidak selalu optimal PT Livia Mandiri Sejati menyadari bahwa pentingnya karyawan untuk jalannya operasional Perusahaan serta sales marketing yang membantu dalam penjualan. Untuk mencapai tujuan atau target Perusahaan maka perlu adanya kesejahteraan karyawan sehingga dapat meningkatkan kinerja. perusahaan PT Livia Mandiri Sejati Banyuwangi terlihat sudah mampu menjaga keberlangsungan hidup suatu perusahaan dan bersaing dengan perusahaan lainnya. Hal ini dapat terlihat bahwa yang telah menjadikan PT Livia Mandiri Sejati Banyuwangi sebagai Perusahaan AMDK terbesar di Banyuwangi adalah sumber daya manusia yang mampu bekerja secara cekatan dan professional. Penelitian ini bertujuan unuk menganalisis pengaruh kompensasi, motivasi dan disiplin kerja terhadap kinerja karyawan pada PT Livia Mandiri Sejati Banyuwangi.

\section{Metode}

Popolasi penelitian ini adalah seluruh karyawan PT Livia Mandiri Sejati Banyuwangi yang berjumlah 98 orang. Mengacu pada pendapat Arikunto (2006) "apabila seorang ingin meneliti semua elemen yang ada dalam wilayah penelitian, maka penelitianya merupakan penelitian populasi atau penelitianya juga disebut study populasi atau study sensus". Dari penelitian tersebut, maka pnelitian ini merupakan penelitian populasi yaitu meneliti seluruh populasi yang ada meliputi seluruh karyawan di PT Livia Mandiri Sejati Banyuwangi sebanyak 98 orang. 


\section{Hasil dan pembahasan}

Pengujian Validitas dan Reabilitas Data

Hasil uji validitas terlihat bahwa korelasi antara masing-masing indikator terhadap total skor konstruk dari setiap variabel menunjukkan hasil yang valid, hal ini karena $r$ hitung $>r$ tabel dan nilai signifikasi $<0,05$. Sehingga dapat disimpulkan bahwa semua item pernyataan dinyatakan valid. Hasil uji reliabilitas tersebut menunjukkan bahwa semua variabel mempunyai koefisien alpha yang cukup atau memenuhi criteria untuk dikatakan reliable yaitu $>0,700$, sehingga untuk selanjutnya item-item pada masing-masing konsep variabel tersebut layak digunakan sebagai alat ukur.

Pengujian Asumsi Klasik

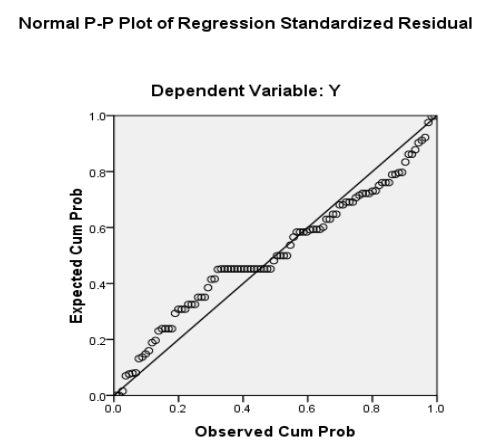

Gambar 1. Hasil pengujian Asumsi Klasik

Setelah dilakukan pengujian ternyata semua data terdistribusi secara normal, sebaran data berada disekitar garis diagonal. Hal ini menunjukkan bahwa model regresi dalam penelitian ini memenuhi asumsi normalitas.

Tabel 1. Hasil Uji Multikolonearitas

\begin{tabular}{llll}
\hline No & Variabel & Nilai Tolerance & Nilai VIF \\
\hline 1 & Kompensasi $\left(\mathrm{X}_{1}\right)$ & 0,587 & 1,705 \\
2 & Motivasi $\left(\mathrm{X}_{2}\right)$ & 0,569 & 1,758 \\
3 & Disiplin kerja $\left(\mathrm{X}_{3}\right)$ & 0,534 & 1,873 \\
\hline
\end{tabular}

Dari tabel menunjukkan bahwa nilai VIF semua variabel bebas dalam penelitian ini lebih kecil dari 10 sedangkan nilai toleransi semua variabel bebas lebih dari $10 \%$ yang berarti tidak terjadi kolerasi antar variabel bebas dengan demikian dapat disimpulkan bahwa tidak terdapat gejala multikolinearitas antar variabel bebas dalam model regresi

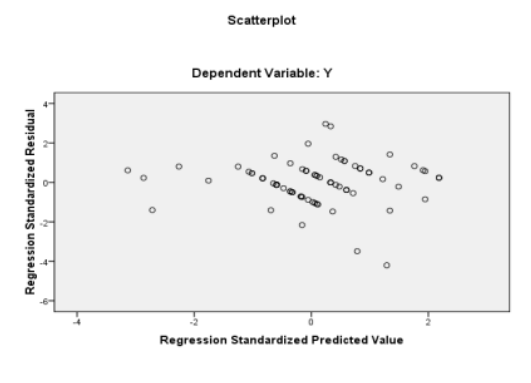

Gambar 2. Hasil Uji Heteroskedastisitas

Dari hasil uji heteroskedastisitas yang telah dilakukan, ternyata titik-titik menyebar secara acak, tidak membentuk suatu pola tertentu yang jelas serta tersebar baik diatas maupun dibawah angka 0 (nol) pada sumbu Y, hal ini berarti tidak terjadi penyimpangan asumsi klasik heteroskedastisitas pada model regresi yang dibuat, dengan kata lain menerima hipotesis homoskedastisitas. 
Hasil Analisis Regresi Linier Berganda

Analisis regresi digunakan untuk menguji hipotesis tentang pengaruh secara parsial variabel bebas terhadap variabel terikat.

Tabel 2. Hasil Regresi Linear Berganda

\begin{tabular}{lllll}
\hline No & Variabel & Koefisien Regresi & t hitung & Signifikasi \\
\hline 1 & Konstanta & 1,008 & 1,298 & 0,198 \\
2 & Kompensasi $\left(\mathrm{X}_{1}\right)$ & 0,415 & 5,359 & 0,000 \\
3 & Motivasi $\left(\mathrm{X}_{2}\right)$ & 0,234 & 3,394 & 0,001 \\
4 & Disiplin Kerja $\left(\mathrm{X}_{3}\right)$ & 0,268 & 3,483 & 0,001 \\
\hline
\end{tabular}

dapat diketahui persamaan regresi yang terbentuk adalah :

$$
Y=1,008+0,415 X_{1}+0,234 X_{2}+0,268 X_{3}
$$

Hasil perhitungan uji T dengan menggunakan progam spss dapat dilihat berdasarkan tabel tersebut dapat diketahui besarnya pengaruh masing-masing variabel bebas terhadap variabel terikat sebagai berikut:

Hasil uji kompensasi mempunyai nilai signifikasi hitung sebesar 0,000 dan sama dengan 0,05 dan $\mathrm{t}$ hitung $(5,359)>t_{\text {tabel }}(1.6612)$ yang berarti bahwa hipotesis Kompensasi mempunyai pengaruh signifikan terhadap kinerja karyawan diterima. Hal ini juga menunjukkan bahwa kompensasi mempengaruhi kinerja karyawan yang berarti semakin banyak kompensasi akan berdampak pada semakin baik pada kinerja karyawan.

Hasil uji motivasi mempunyai nilai signifikasi hitung sebesar 0,001 dan lebih besar dari 0,05 dan $\mathrm{t}$ hitung $(3,394)>t$ tabel $(1.6612)$ yang berarti bahwa hipotesis motivasi mempunyai pengaruh signifikan terhadap kinerja karyawan diterima. hal ini juga menunjukkan bahwa motivasi mempengaruhi kinerja karyawan yang berarti semakin baik motivasi akan berdampak baik terhadap kinerja karyawan.

Hasil uji disiplin kerja mempunyai nilai signifikasi hitung sebesar 0,001 dan lebih kecil dari 0,05 dan $t$ hitung $(3,483)>t$ tabel $(1.6766)$ yang berarti bahwa hipotesis disiplin kerja mempunyai pengaruh signifikan terhadap kinerja karyawan diterima. hal ini juga menunjukkan bahwa disiplin kerja mempengaruhi kinerja karyawan yang berarti semakin disiplin akan berdampak baik terhadap kinerja karyawan.

\section{Simpulan dan saran}

Dari pengujian secara statistik yang telah dilakukan, maka dapat ditarik kesimpulan sebagai berikut. Hasil pengujian secara statistik telah membuktikan bahwa variabel disiplin kerja berpengaruh signifikan terhadap variabel Kinerja Karyawan. Maka harus mempertahankan disiplin kerjanya dalam hal ini disiplin kerja mampu menjadi salah satu faktor pendorong kinerja karyawan pada PT Livia Mandiri Sejati Banyuwangi. Hasil pengujian secara statistik telah membuktikan bahwa variabel kompensasi berpengaruh signifikan terhadap variabel kinerja karyawan. Hal ini berarti, kompensasi mampu menjadi salah satu faktor pendorong kinerja karyawan pada PT Livia Mandiri Sejati Banyuwangi.

Hasil pengujian secara statistik telah membuktikan bahwa variabel motivasi kerja berpengaruh signifikan terhadap variabel kinerja karyawan. Hal ini berarti, motivasi mampu menjadi salah satu faktor pendorong kinerja karyawan pada PT Livia Mandiri Sejati Banyuwangi.

\section{Daftar Rujukan}

Arikunto, Suharsimi. 2006. Prosedur Penelitian (Suatu Pendekatan Praktik). Jakarta: PT. Rineka Cipta.

Ayer. Johanes Elizer, Panggemanan. Lyndon R. J, Rori. P I Yolanda, 2016. Pengaruh motivasi dan disiplin kerja terhadap kinerja pegawaipada dinas pertanian kabupaten supiori. sosialekonomi Unsrat.

Fadilah. Rozi, Sulastini, Hidayati. Noor. 2017.Pengaruh Kompetensi, Disiplin Kerja Dan Lingkungan Kerja Terhadap Kinerja Karyawan Pada Kantor Bank Kalsel Cabang Pembantu Di Banjarmasin.Universitas Banjarmasin.

Mondy, R. Wayne. 2008. Manajemen Sumber Daya Manusia. Penerbit Erlangga, Jakarta. 
Muawanah, Siti. Sudapet, I Nyoman2016. Pengaruh Motivasi, Disiplin Kerja Dan Kepuasan Kerja Terhadap Kinerja Karyawan PT Jadi Abadi Corak Biscuit. Universitas Narotama Surabaya.

Purnomo. Muhammad Heru, Dwiloka. Bambang. 2017. Pengaruh Motivasi, Kompensasi Dan Komunikasi Pimpinan Terhadap Kinerja Karyawan Pt. Bank Jateng Cabang Temanggung. Universitas Jawa tengah

Rivai. Veithzal 2015. Performance Appraisal Sistem Yang Tepat Untuk Menilai Kinerja Karyawan Dan Meningkatkan Daya Saing Perusahaan. PT Raja Grafindo Persada, Jakarta.

Rivai. Veithzal. 2006. Manajemen Sumber Daya Manusia Untuk Perusahaan. Jakarta. PT. Raja Grafindo Persada.

Rivai. Veithzal. 2011. Manajemen Sumber Daya Manusia Untuk Perusahaan. Edis Kedua. PT. Raja Grafindo Persada, Bandung.

Santoso B, Nursaidah ,2017, Peranan Variabel Moral pegawai, komitmen pegawai, motivasi pegawai dan pengaruhnya OCB Pegawai terhadap Quality service (Studi Lembaga Pendidikan Muhamadiyah di Kabupaten Jember), Jurnal ilmu Manajemen dan Bisnis UM Jember Vol 3 No.2

Siagian, Sopar Sihar Imanuel. Khuzaini.2015. Pengaruh Pelatihan, Kepuasan Kompensasi, Motivasi Dan Disiplin Kerja Terhadap Kinerja Karyawan. ilmu dan riset manajemen volume.

Sutrisno,Edi, 2009. Manajemen Sumber Daya Manusia, Edisi Pertama, Kencana Prenada media Group. Jakarta

Werther, Davis, 1996. Human Resources And Personal Managemen. International edition. Mcgrau-hill, inc. USA

Wibowo, 2011. Manajemen Sumber Daya Manusia. Prenada media Group. Jakarta

Wibowo. 2014. Manajemen Kinerja (edisi ke 5). Jakarta :Rajawali Pers. 